\title{
The microbiome of the upper airways: focus on chronic rhinosinusitis
}

\author{
Thanit Chalermwatanachai ${ }^{1,2}$, Leydi Carolina Velásquez ${ }^{1,3}$ and Claus Bachert ${ }^{1,4^{*}}$
}

\begin{abstract}
Upper airway diseases including allergic rhinitis, chronic rhinosinusitis with or without polyps, and cystic fibrosis are characterized by substantially different inflammatory profiles. Traditionally, studies on the association of specific bacterial patterns with inflammatory profiles of diseases had been dependent on bacterial culturing. In the past 30 years, molecular biology methods have allowed bacterial culture free studies of microbial communities, revealing microbiota much more diverse than previously recognized including those found in the upper airway.

At presence, the study of the pathophysiology of upper airway diseases is necessary to establish the relationship between the microbiome and inflammatory patterns to find their clinical reflections and also their possible causal relationships. Such investigations may elucidate the path to therapeutic approaches in correcting an imbalanced microbiome. In the review we summarized techniques used and the current knowledge on the microbiome of upper airway diseases, the limitations and pitfalls, and identified areas of interest for further research.
\end{abstract}

\section{Introduction}

It is generally believed that exposure to microorganism compromises health. Reduced exposure to microbiota results in decrease of incidence of infectious diseases but may adversely increase the incidence of allergic disorders [1-3]. Recent developments of culture-independent tools make it possible to identify microbial species not previously detected by conventional methods. Unbeknownst to us, man had been living with these microoraganisms since the dawn of time.

The human body harbors from 10 to 100 trillion microbes which greatly outnumber our own human cells [4]. This bacterial assemblage has been coined, "the human microbiota" [4]. Subsequently, a project called "Human Microbiome" was established to investigate the flora in healthy volunteers and their relationship to human health and disease [5]. The study of the host-microbe relationship has shown that microbes play a major role in our well-being $[4,6]$. Alterations of microbial composition have been linked to several human diseases [4]. There is also evidence showing that, in the respiratory system, composition of airway microbiota varies between healthy

\footnotetext{
* Correspondence: Claus.Bachert@UGent.be

'Department of Oto-Rhino-Laryngology, The Upper Airways Research Laboratory (URL), Ghent University Hospital, Ghent 9000, Belgium

${ }^{4}$ Division of ENT Diseases, Clintec, Karolinska Institutet, Stockholm, Sweden

Full list of author information is available at the end of the article
}

people and people with diseases such as asthma [6-8] and cystic fibrosis (CF) $[8,9]$. Unfortunately, with limited studies currently available, it cannot be concluded with the same degree for chronic rhinosinusitis (CRS) [10].

Research on microbiome in CRS is therefore needed to elucidate pathophysiology of this disease such as; 1) the relationship between the microbiome and inflammatory patterns, 2) possible causal relationships between microbe and CRS, 3) investigation of the microbiome regarding possible therapeutic properties. Dysregulation of the interactions between the immune system and commensal bacteria is a contributing factor to the development and chronicity of a number of inflammatory diseases [11]. Microorganisms in the gut may play a significant role in regulating $\mathrm{T}$ helper cells (Th cells), regulatory $\mathrm{T}$ cells (Tregs) and dendritic cells as well as Toll-like receptor expression in sentinel cell (macrophage and dendritic cells) which are relevant to airway illnesses such as asthma and allergic diseases [10].

\section{Techniques in microbiota study}

Principal approaches to analyze human microbiota are: culture-dependent and culture-independent techniques. Culture-dependent methods involve isolation and culturing of microorganisms prior to their identification according to morphological, biochemical or genetic characteristics. These methods are time-consuming, due to culture 
and bias, as certain media and growth conditions favor the growth of some bacteria over others [12]. In addition, this approach may not provide a true reflection of the diversity of microbes in a sample. A "no growth" result does not necessarily imply that a sample is sterile. It is estimated that up to $99 \%$ of microorganisms observable in nature typically cannot be cultured by standard techniques [13]. Un-cultivability is a widespread condition that includes: (i) organisms for which the specific growth requirements (nutritional, temperature, aeration, etc.) are not fulfilled; (ii) slow-growing organisms are out-competed in the presence of fast-growing microorganisms and (iii) disfavored organisms, which cannot stand the stressful conditions imposed by cultivation $[13,14]$. This approach camouflages the true bacterial community. There needed to be a better approach to analyze these microorganisms.

Since the 1980s, the application of molecular detection methods has allowed culture-independent investigations of the microbial communities [15]. Molecular techniques have proven effective in characterizing complex microbial assemblages in environmental samples [16]. However, an important usefulness of molecular techniques is the ability to detect genetic materials of non-viable microorganisms $[17,18]$. Culture-independent methods are based on the direct analysis of bacterial DNA (or RNA) without culturing. Due to the sensitivity of these techniques, special care and attention is required for procedures that include sample collection and handling, DNA extraction, amplification of gene fragments, distinction of different fragments, identification of microorganism and analysis of the microbial community [15].

For bacterial identification, the predominant gene target for amplification has been the $16 \mathrm{~S}$ ribosomal RNA gene (or 16S rRNA) [19,20], which is a component of the $30 \mathrm{~S}$ small subunit of prokaryotic ribosomes [21]. It has been widely targeted because of (i) its presence in almost all bacteria, often existing as a multigene family, or as operon; (ii) the conservation of the $16 \mathrm{~S}$ rRNA gene, suggesting that random sequence changes are a measure of time (evolution) rather than a reflection of different bacteria; and (iii) the size of $16 \mathrm{~S}$ rRNA genes (1,500 bp) being large enough for informatic purposes [22]. Moreover, there are several available reference sequences and taxonomies databases such as Greengenes, SILVA and the Ribosomal database project [23]. However, amplification of target genes using polymerase chain reaction (PCR) has made it impossible to completely avoid PCRbased biases and chimera production. It thus may distort the level of diversity and bacterial composition in a sample because of the amplification of pseudogenes [24]. Therefore, other technologies are often used as complementary approaches to $16 \mathrm{~S}$ rRNA gene sequencing for reducing distortion of bacterial diversity and composition. They are DNA microarray, fluorescence in situ hybridization
(FISH), and quantitative PCR (qPCR), and are based on oligonucleotide probes and primers that target the ribosomal RNA sequences or other genes in different hybridization procedures. Thus these techniques require a prior knowledge of the microbial DNA sequence. A DNA microarray (also commonly known as DNA chip or biochip) is a collection of microscopic DNA spots (oligonucleotide probes) attached to a solid surface. It is usually used for gene expression analysis or screening of single nucleotide polymorphisms. The FISH technique uses fluorescent probes that bind to only those parts of the chromosome with which they show a high degree of sequence complementarity. It detects and localizes the presence of specific DNA sequences on chromosomes. qPCR or real-time PCR follows the general principle of PCR with the advantage of detecting the amount of initial DNA in samples using either fluorescent DNA-binding dyes or fluorescence-tagged oligonucleotide probes [15].

The introduction of next generation sequencing changed the history of genomic research as it increased sequencing throughput, and did not require prior cloning steps [25]. These technologies are not only changing our genome sequencing approaches and the associated timelines and costs [26], but also developing many exciting fields such as metagenomics, metatranscriptomics and single-cell genomics [15]. Three platforms for high throughput parallel DNA sequencing are in reasonably widespread use at present: the Roche/454 FLX, the Illumina (MiSeq, HiSeq, and NextSeq), and the Ion Torrent.

At presence, researchers have a large choice in formulating methodological strategies: depending on the access to the technology, budget, and objectives of research. Each culture-independent methodology has its own limitations and biases, investigators must take additional measures; for example one may use more than one molecular technique or a culture-dependent approach in parallel to provide additional validation of results and reduce the possibility of false findings due to methodological errors and biases. Although the culture-independent techniques have the ability to detect more microbes than culture technique, the culture-dependent methods so far remain a better means of obtaining individual isolates contributing and obtaining isolates for further assays.

\section{Microbiota in allergic rhinitis}

As the gate into our body, the respiratory tract itself harbors a heterogeneous microbiota that decreases in biomass from upper to lower tract [27]. Even in health, recent findings indicated that direct exposure to bacterial communities in the airways may provide an explanation for how commensal bacteria can regulate chronic airway inflammation [11]. Since the observation that infections within households in early childhood have a role in preventing allergic rhinitis [3], numerous epidemiologic 
and experimental studies have sought to clarify and extend the so-called hygiene hypothesis with respect to asthma and other allergic and autoimmune disorders. The evidence supporting the hygiene hypothesis established the "microbiota (microflora) hypothesis". This concept proposes that perturbations in gastrointestinal bacteria have disrupted the mechanisms of mucosal immunologic tolerance, which has led to an increase in the incidence of allergic airway disease [28]. Independent studies found that a reduced diversity of the gut microbiota in infancy is associated with an increased risk of allergic manifestation at school age [29-31]. The association between the composition of microbiota in the intestine, asthma and allergic disease is nowadays of high interest [32,33], although the exact mechanism of the interaction of intestinal-systemic immunity is still not defined [34,35]. There are several publications reviewing the relationships between intestinal microbes and asthma $[7,10,36]$. Suggesting that the intestinal microbiome contributes to the regulation of local and systemic inflammatory responses via short-chain fatty acids, a product of fermentation of dietary fibers by intestinal bacteria [11]. Following this model, it is likely that the respiratory microbiota may also have an impact on airway inflammation in allergic responses [1,11], however, this needs further investigation.

\section{Microorganisms in the airways of cystic fibrosis patients}

Cystic fibrosis (CF) is an autosomal recessive genetic disorder that affects among other organs the lungs and sinuses. It is characterized by abnormal transport of chloride and sodium across the epithelium, leading to thick, viscous secretions. This leads to defective mucociliary clearance and chronic airway infection with a complex microbiota [37]. Lung disease in cystic fibrosis results from chronic airway infection and inflammation leading to progressive bronchiectasis and respiratory failure [38]. Specimens for molecular microbial analysis in CF have for the most part all derived from sputum [37,39-42], while swabs from the middle meatus in patients with sinusitis were not used until now. Thus, no conclusions can be made for the upper airways yet. Samples consisted of serial collections of more than six patients in most of the studies $[37,42-44]$.

Previous studies indicated that exacerbations might be associated with changes in microbial densities and the acquisition of new microbial species [37]. Bacterial pathogens, including Pseudomonas aeruginosa, Staphylococcus aureus, and Burkholderia cepacia are known contributors to such exacerbations. Recent studies using the latest culture-dependent techniques and culture-independent molecular techniques have broadened our view of CF airway bacterial communities [38]. Each CF patient presented a unique microbiome [40]. The species present tended to vary more "between" than "within" subjects, suggesting that each CF airway infection is unique, with relatively stable and resilient bacterial communities [44]. The diversity and species richness of fungal and bacterial communities were significantly lower in patients with decreased lung function and poor clinical status [39]. The authors observed a strong positive correlation between low species richness and poor lung function [37]. These findings show the critical relationship between airway bacterial community structure, disease stage, and clinical state at the time of sample collection [42].

The main microorganisms found in CF airways are the genera Haemophilus, Pseudomonas, Staphylococcus and Stenotrophomonas. Less common are gram-negatives, Streptococcus and Mycobacterium spp [45]. Most bacteria of CF airways are difficult to culture using conventional clinical methods; therefore, molecular approaches may confirm or reveal novel bacteria that might be related to the pathogenesis of cystic fibrosis. Examples of interest are the Streptococcus milleri group (Streptococcus anginosus, Streptococcus intermedius, Streptococcus constellatus) [46], Pseudomonas intermedia [46], and Gemella species [47] (Table 1). Further experiments suggested that these bacteria could act as co-pathogens or enhance the virulence of conventional CF pathogens [48].

\section{The microbiome in chronic rhinosinusitis}

Specimen collection is one of the most important steps in the analysis of remote areas such as the sinuses. An appropriate collection of the samples is the first step to perform a meaningful, high quality analysis. It must not be biased by interference from the nares. Specimen can be tissue, nasal secretions [55] or material sampled by a swab. The use of an endoscope for the sampling during sinus surgery is advisable $[17,18,56]$, although simple swabs are often used [57] in both healthy and diseased patients [18]. Samples can be collected from various anatomical locations in the nose such as the inferior turbinate [55], the middle-meatus [56], the ethmoidal sinuses, the sphenoid [18], and the anterior nasal cavity [58]. Mucosal surfaces of the lateral, central, and medial portions of the maxillary sinus are also collected from locations in the nose [17]. The use of middle-meatus swabs for DNAbased bacterial assays is appropriate for the detection of multiple bacterial species, including anaerobes, which may be undetected when swabs are used solely for culture. Based on available cultivation-based studies, the microbiology of the middle meatus correlates well with pathogenic organism of CRS, whereas swabs of the nares would not be appropriate as a replacement of middle meatus swabs in investigations of CRS pathogen [59]. Swabs should not be contaminated by the microorganism of the nares during insertion/retraction from the middle meatus or sinuses [56]. To avoid contamination by the nasal vestibule, researchers often use appropriate protective 
Table 1 Summary of cystic fibrosis microbiota studies; type of sample, technique used and genus identified

\begin{tabular}{|c|c|c|c|c|c|c|c|c|c|}
\hline Author & Year & $n$ & Sample & Techinque & Achromobacter & Actinomyces & Atopobium & Bacteroidetes & Burkholderia \\
\hline Salipante SJ * & 2013 & $60 \mathrm{CF}$ & Sputum & 16 s rRNA pyrosequencing & & & & & \\
\hline Zemanick ET & 2013 & $37 \mathrm{CF}$ & Sputum & $\begin{array}{l}\text { Conventional culture } 16 \mathrm{~S} \text { rRNA } \\
\text { pyrosequencing }\end{array}$ & & $x$ & $x$ & & \\
\hline Delhaes L & 2012 & $8 \mathrm{CF}$ & Sputum & $\begin{array}{l}\text { Conventional culture } 16 \mathrm{~S} \text { rRNA } \\
\text { pyrosequencing }\end{array}$ & & & & & \\
\hline Fodor AA & 2012 & $23 \mathrm{CF}$ & Sputum & $16 \mathrm{~S}$ rRNA pyrosequencing & & & & & $x$ \\
\hline Stressmann FA ** & 2012 & $14 \mathrm{CF}$ & Sputum & Conventional culture analysis T-RFLP & & & & & \\
\hline Zhao J & 2012 & $6 \mathrm{CF}$ & Sputum & 16 s rRNA pyrosequencing & & & & & \\
\hline Guss AM & 2011 & $4 \mathrm{CF}$ & Sputum & 16 s rRNA pyrosequencing & & $x$ & & $x$ & \\
\hline Sibley CD & 2011 & $6 \mathrm{CF}$ & Sputum & $\begin{array}{l}\text { Conventional culture T-RFLP } 16 S \text { rRNA } \\
\text { pyrosequencing }\end{array}$ & $x$ & $x$ & & $x$ & $x$ \\
\hline $\operatorname{Cox} M J^{* * *}$ & 2010 & $63 \mathrm{CF}$ & Sputum Throat swab & Microarray & & & & & \\
\hline J Harris JK **** & 2007 & 28 CF 14 healthy & Bronchoalveolar lavage fluid & DGGE/TGGE & & & & & \\
\hline Rogers GB ***** & 2004 & $34 \mathrm{CF}$ & Sputum & T-RFLP & & & & & \\
\hline
\end{tabular}


Table 1 Summary of cystic fibrosis microbiota studies; type of sample, technique used and genus identified (Continued)

\begin{tabular}{|c|c|c|c|c|c|c|c|c|c|}
\hline Author & Campylobacter & Capnocytophaga & Craurococcus & Fusobacterium & Granulicatella & Haemophilus & Lactobacillus & Leptotrichia & Ochrobactrum \\
\hline Salipante SJ * & & & & & & $x$ & & & \\
\hline Zemanick ET & $x$ & $x$ & & $x$ & $x$ & & $x$ & $x$ & \\
\hline Delhaes L & & & & $x$ & & $x$ & & & \\
\hline \multicolumn{10}{|l|}{ Fodor AA } \\
\hline \multicolumn{10}{|l|}{ Stressmann FA ** } \\
\hline Zhao J & & & & $x$ & & & & & \\
\hline Guss AM & & & & $x$ & & & & & \\
\hline Sibley CD & & & & & & $x$ & & & \\
\hline \multicolumn{10}{|l|}{ Cox MJ*** } \\
\hline J Harris JK **** & & & & & & $x$ & & & \\
\hline Rogers $\mathrm{GB} * * * * *$ & & & $x$ & & & & & & $x$ \\
\hline
\end{tabular}


Table 1 Summary of cystic fibrosis microbiota studies; type of sample, technique used and genus identified (Continued)

\begin{tabular}{|c|c|c|c|c|c|c|c|c|c|c|c|}
\hline Author & Peptostreptococcus & Porphyromonas & Prevotella & Pseudomonas & Rhizobium & Rothia & Staphylococcus & Stenotrophomonas & Streptococcus & Veillonella & Ref. \\
\hline Salipante SJ * & & & & $x$ & & & & $x$ & $x$ & & {$[49]$} \\
\hline Zemanick ET & & $x$ & $x$ & $x$ & & $x$ & $x$ & & $x$ & $x$ & [35] \\
\hline Delhaes $L$ & & $x$ & $x$ & $x$ & & & & & $x$ & $x$ & [39] \\
\hline Fodor AA & & & $x$ & $x$ & & $x$ & & & $x$ & $x$ & [37] \\
\hline Stressmann FA ** & & & & $x$ & & & $x$ & $x$ & $x$ & & [44] \\
\hline Zhao J & & & $x$ & $x$ & & $x$ & & & $x$ & $x$ & [41] \\
\hline Guss AM & & $x$ & $x$ & & & $x$ & & & $x$ & $x$ & {$[50]$} \\
\hline Sibley CD & & & $x$ & $x$ & & & $x$ & $x$ & $x$ & $x$ & [51] \\
\hline $\operatorname{Cox} \mathrm{MJ}^{* * *}$ & & & & $x$ & & & $x$ & & & & {$[52]$} \\
\hline J Harris JK **** & & & & $x$ & & & $x$ & & $x$ & & [53] \\
\hline Rogers GB ***** & $x$ & $x$ & $x$ & $x$ & $x$ & & & & & & {$[54]$} \\
\hline
\end{tabular}

*Stenotrophomonas maltophilia, Streptococcus agalactiae, Haemophilus influenzae, Pseudomonas aeruginosa.

**P. aeruginosa, Stenotrophomonas maltophili', Staphylococcus aureus, Streptococcus Group F.

***S. aureus, $P$. aeruginosa.

***S. aureus, S. maltophilia, P. aeruginosa, Streptococcus mitis, H. influenza.

*****P. aeruginosa, Porphyromonas endodontalis, P. gingivalis, Prevotella denticola, P. melaninogenica, P. nigrescens, P. veroralis, P. intermedia, P. loescheii, P. salivae, P. buccae, P. oris, Craurococcus roseus, Rhizobium loti, Ochrobactrum anthropi, Peptostreptococcus anaerobius.

Asterisks indicate studies in which mentioned species were identified. 
devices such as a sterilized Killian nasal speculum with long leaves [58].

Before the era of culture-independent methods, conventional cultures have implicated Staphylococcus aureus and coagulase-negative Staphylococcus as principal pathogens in chronic rhinosinusitis (CRS) [60]. The development of culture-independent molecular techniques allowed the detection of more bacteria [60] and revealed greater biodiversity than conventional culture [56]. Thus, the etiology of CRS may be polymicrobial [55] and the role of anaerobe bacteria may be more prominent than presumed; however, it is likely that the bacteria detected by culture-dependent techniques still are of clinical relevance [60].

Using comparative microbiome profiling in a cohort of a small number of not further defined CRS patients and healthy subjects, it was proposed that the sinus microbiota of CRS patients exhibit significantly reduced bacterial diversity compared to those of healthy controls. Abreu et al., found a depletion of multiple phylogenetically distinct lactic acid bacteria coincident with an increase in the relative abundance of a single species, Corynebacterium tuberculostearicum [17]. These microbe caused goblet cell hyperplasia and mucin hypersecretion in a murine model of sinus infection. In this model, Lactobacillus sakei represented a potentially protective species [17]. However, the finding of this single species has not been confirmed by others $[55,56]$ (see Table 2). In a larger study, Staphylococcus aureus and Propionibacterium acnes were the most common organisms in CRS (mostly CRSwNP) and controls, respectively [18]. Recently, the investigators detected Staphylococcus aureus, Staphylococcus epidermidis and Propionibacterium acnes as the most prevalent and abundant microorganisms in healthy sinuses [61].

Using culture-independent (qPCR and 16S rRNA gene sequencing) methodologies for pathogen identification in chronic rhinosinusitis patients, among 57,407 pyrosequences were generated. The most prevalent ones were from coagulase-negative staphylococci (100\%), 21/21 specimens, Corynebacterium spp (not specifically Corynebacterium tuberculostearicum) (85.7\%) 18/21, P. acnes (76.2\%), 16/21, and Staphylococcus aureus (66.7\%) 14/21. Although these authors found significantly different distributions of 16S rRNA sequences recovered from CRS vs. non-CRS cases, neither richness nor evenness indices showed statistically significant differences [56]. In another approach using $16 \mathrm{~S}$ rRNA gene clone sequencing in a terminal restriction fragment length polymorphism (T-RFLP) analysis, the bacteria present in 70 clinical samples from 43 CRS patients undergoing endoscopic sinus surgery were characterized; a total of 48 separate bands were detected. Species belonging to 34 genera were identified as present by clone sequence analysis. Of the species detected, those within the genera Pseudomonas, Citrobacter, Haemophilus, Propionibacterium, Staphylococcus, and Streptococcus were found numerically dominant, with Pseudomonas aeruginosa being the most frequently detected species [55]. Another prospective study collected mucosal biopsies from 18 patients undergoing endoscopic sinus surgery for CRS and 9 control patients with healthy sinuses (indication: pituitary adenomas) compared swab culture with bTEFAP (bacterial tag-encoded FLX amplicon pyrosequencing). Standard cultures mainly showed Staphylococcus aureus and Coagulase-negative Staphylococcus aureus, whereas the molecular analysis identified up to 20 predominant organisms per sample. Staphylococcus aureus was nevertheless detected in about 50\%; moreover, they disclosed anaerobic species with so far unknown impact in CRS, Diaphorobacter and Peptoniphilus. Interestingly, Diaphorobacter is described as a strong biofilm creator [55,60].

Table 2 provides a summary of previous studies related to the microbiome in chronic rhinosinusitis, including sample size, type of sample, technique used and genus found.

Comparisons of molecular analyses suggest that the detection of microorganisms by Fluorescence in-situ hybridization (FISH) and culture-dependent techniques is related to the abundance of an organism, furthermore, cultivation tends to give advantage to rapidly growing bacteria [18]. The investigators employed conventional cultivation, molecular diagnostics and FISH to detect Staphylococcus aureus as a standard. They found that FISH analysis had a sensitivity of $78 \%$ with a specificity of $93 \%$ compared to the molecular technique [18]. Evidence from high-sensitivity techniques demonstrates that the healthy sinus is clearly not sterile [18], but shows high diversity of the resident microbiota [17]. The nasal microbiota of healthy subjects mainly consist of members of the phylum Actinobacteria (e.g., Propionibacterium spp. and Corynebacterium spp.), whereas the phyla Firmicutes (e.g., Staphylococcus spp.) and Proteobacteria (e.g. Enterobacter spp) are less frequent $[55,56,60,63]$. It appears that the prevalence and abundance of organisms is critical in determining healthy conditions [18].

Thus, similar to CF, findings in CRS have pointed out that the microbiome is unique for each individual patient [42-44] and the community of microbes is diversified [10]. As a general principle, a decreasing bacterial diversity is correlated with disease severity in CF [37-39,42,44], whereas CRS patients were characterized by an altered microbial composition and greater abundance of Staphylococcus aureus [56]. There was no single common microbiota profile among patients with similar clinical conditions in the studies performed so far, although Staphylococcus aureus was prominent in most studies $[10,11,68]$. Thus, there is a clear need for larger series 
Table 2 Summary of chronic rhinosinusitis microbiota studies; type of sample, technique used and genus identified

\begin{tabular}{|c|c|c|c|c|c|c|c|}
\hline Author & Year & $n$ & Sample & Techinque & Aureobacterium & Alicycliphilus & Burkholderia \\
\hline Ramakrishnan VR et al.* & 2013 & 28 healthy & Middle meatus swab & qPCR 165 rRNA pyrosequencing & & & \\
\hline Aurora R et al. & 2013 & 30 CRS 12 healthy & Superior middle meatus lavage & 16S rRNA pyrosequencing & & $x$ & \\
\hline Boase $S$ et al.** & 2013 & 38 CRS 6 healthy & Mucus Middle meatus swab & Conventional culture Ibis T5000 & & & \\
\hline Abreu NA et al. & 2012 & 10 CRS 10 healthy & $\begin{array}{l}\text { Brush samples of mucosal surfaces } \\
\text { of the lateral, central, and medial } \\
\text { portions of the maxillary sinus }\end{array}$ & PhyloChip analysis & & & $x$ \\
\hline Feazel LM et al.** & 2012 & 15 CRS 5 healthy & Middle meatus swabs & $\begin{array}{l}\text { Conventional culture } 16 \mathrm{~S} \text { rRNA } \\
\text { pyrosequences }\end{array}$ & & & \\
\hline Stressmann FA et al..** & 2011 & 43 CRS. & $\begin{array}{l}\text { Polyp and inferior turbinate tissue. } \\
\text { Mucin (if present) }\end{array}$ & $16 \mathrm{~S}$ rRNA pyrosequencing T-RFLP & & & \\
\hline Frank DN et al..*** & 2010 & $\begin{array}{l}26 \mathrm{~S} \text {. aureus carriers } \\
16 \text { non-carriers } 5 \\
\text { healthy }\end{array}$ & Nostril swabs & 16S rRNA pyrosequencing & & & \\
\hline Stephenson MF et al..**** & 2010 & 18 CRS 9 healthy & Mucosal Biopsy & $16 \mathrm{~s}$ rRNA pyrosequencing & & & \\
\hline Healy DY et al..***** & 2008 & 11 CRS 3 healthy & Mucosa samples & $\begin{array}{l}\text { FISH DNA probes Haemophilus influenzae } \\
\text { Streptococcus pneumophilia Staphylococcus } \\
\text { aureus Pseudomonas aeruginosa }\end{array}$ & & & \\
\hline Sanderson AR et al.****** & 2006 & 18 CRS 5 healthy & Biopsies of the sinus mucosa & $\begin{array}{l}\text { FISH DNA probes Haemophilus influenzae } \\
\text { Streptococcus pneumophilia Staphylococcus } \\
\text { aureus Pseudomonas aeruginosa }\end{array}$ & & & \\
\hline Lina $\mathrm{G}$ et al..****** & 2003 & 216 healthy & Nasal vestibule swabs & Conventional culture & & & \\
\hline Rasmussen $\Pi$ et al. ${ }^{* * * * * * *}$ & 2000 & 10 healthy & Nasal washes & Conventional culture Capillary sequencing & $x$ & & \\
\hline
\end{tabular}


Table 2 Summary of chronic rhinosinusitis microbiota studies; type of sample, technique used and genus identified (Continued)

\begin{tabular}{|c|c|c|c|c|c|c|c|c|c|}
\hline Author & Carnobacterium & Citrobacter & Cloacibacterium & Corynebacterium & Curtobacterium & Cyanobacterium & Diaphorobacter & Enterobacter & Enterococcus \\
\hline Ramakrishnan VR et al.* & & & & $x$ & & & & $x$ & \\
\hline Aurora R et al. & & & $x$ & $x$ & $x$ & $x$ & & & \\
\hline \multicolumn{10}{|l|}{ Boase $S$ et al..** } \\
\hline Abreu NA et al. & $x$ & & & $x$ & & & & & $x$ \\
\hline Feazel LM et al.** & & & & $x$ & & & & & \\
\hline Stressmann FA et al..** & & $x$ & & & & & & & \\
\hline Frank DN et al.**** & & & & $x$ & & & & $x$ & $x$ \\
\hline Stephenson MF et al.***** & & & & & & & $x$ & & \\
\hline \multicolumn{10}{|l|}{ Healy DY et al..***** } \\
\hline \multicolumn{10}{|l|}{ Sanderson AR et al. ${ }^{* * * * * *}$} \\
\hline Lina $\mathrm{G}$ et al..******* & & & & $x$ & & & & & \\
\hline Rasmussen $\Pi$ et al.******** & & & & $x$ & & & & & \\
\hline
\end{tabular}


Table 2 Summary of chronic rhinosinusitis microbiota studies; type of sample, technique used and genus identified (Continued)

\begin{tabular}{|c|c|c|c|c|c|c|c|c|c|}
\hline Author & Fusobacterium & Haemophilus & Helicobacter & Lachnospira & Lactobacillus & Micrococcus & Moraxella & Mycobacterium & Neisseric \\
\hline Ramakrishnan VR et al.* & $x$ & $x$ & & & & & $x$ & & $x$ \\
\hline \multicolumn{10}{|l|}{ Aurora R et al. } \\
\hline \multicolumn{10}{|l|}{ Boase $\mathrm{S}$ et al..* } \\
\hline Abreu NA et al. & & & $x$ & $x$ & $x$ & & & $x$ & \\
\hline \multicolumn{10}{|l|}{ Feazel LM et al.** } \\
\hline Stressmann FA et al..** & & $x$ & & & & & & & \\
\hline \multicolumn{10}{|l|}{ Frank DN et al.**** } \\
\hline \multicolumn{10}{|l|}{ Stephenson MF et al.***** } \\
\hline Healy DY et al..***** & & $x$ & & & & & & & \\
\hline Sanderson AR et al..****** & & $x$ & & & & & & & \\
\hline Lina $\mathrm{G}$ et al..******* & & & & & & $x$ & & & \\
\hline Rasmussen $\Pi$ et al..******** & & & & & & & & & \\
\hline
\end{tabular}


Table 2 Summary of chronic rhinosinusitis microbiota studies; type of sample, technique used and genus identified (Continued)

\begin{tabular}{|c|c|c|c|c|c|c|c|c|c|}
\hline Author & Pediococcus & Peptoniphilus & Propionibacterium & Pseudomonas & Rhodococcus & Staphylococcus & Stenotrophomonas & Streptococcus & $\overline{\text { Ref. }}$ \\
\hline Ramakrishnan VR et al.* & & & $x$ & & & $x$ & $x$ & $x$ & {$[61]$} \\
\hline \multicolumn{10}{|l|}{ Aurora R et al. } \\
\hline Boase $S$ et al..* & & & $x$ & & & $x$ & & & [18] \\
\hline Abreu NA et al. & $x$ & & & $x$ & & & & & {$[17]$} \\
\hline Feazel LM et al.** & & & $x$ & & & $x$ & & & {$[56]$} \\
\hline Stressmann FA et al..** & & & $x$ & $x$ & & $x$ & & $x$ & {$[55]$} \\
\hline Frank DN et al..*** & & & $x$ & & & $x$ & & & [63] \\
\hline Stephenson MF et al..**** & & $x$ & & & & $x$ & & & {$[60]$} \\
\hline Healy DY et al. ${ }^{* * * * *}$ & & & & $x$ & & $x$ & & $x$ & [64] \\
\hline Sanderson AR et al. ${ }^{* * * * * *}$ & & & & $x$ & & $x$ & & $x$ & [65] \\
\hline Lina $\mathrm{G}$ et al. ${ }^{* * * * * * * *}$ & & & & & & $x$ & & $x$ & {$[66]$} \\
\hline Rasmussen $\pi$ et al.******** & & & & & $\mathrm{x}$ & $x$ & & & [67] \\
\hline
\end{tabular}

\section{*S. aureus, P. acnes.}

\section{**P. aeruginosa.}

***S. aureus, S. epidermidis, Propionibacterium acnes.

****S. aureus, S. coagulase-negative, S. anaerobic species.

*****H. influenza, Streptococcus pneumophilia, S. aureus, P. aeruginosa.

******Staphylococcus aureus, S. non-aureus, S. epidermidis, S. capitis, S. haemolyticus, S. warneri, S. hominis, S. lugdunensis, S. cohnii subsp. cohnii, S. auricularis.

*******Haemophilus influenza, S. pneumoniae, S. aureus, Pseudomona aeruginosa.

*******Staphylococcus epidermis. S. capitis, S. hominis. S. haemolyticus, S. lugdunensis, S. warneri

Asterisks indicate studies in which mentioned species were identified. 
of well-defined patients sampled and investigated in an optimal way, also avoiding the interference of recently applied antibiotics, to establish the correlation between microbe and CRS disease.

\section{Limitations of the current studies}

Airway microbiome studies revealed several critical factors, which also may impact CRS studies. First of all, the inclusion of well-defined patients, using pheno- and potentially endotypes of upper airway disease [68-71], and matched controls in meaningful numbers is necessary to draw supportable conclusions. Furthermore, recent antibiotic treatment within 1 month [44] prior to collection could significantly reduce the diversity of the microbiome in samples $[42,43,56]$, and contamination by bacteria from other organs such as the skin should be taken into account $[9,27]$. Factors which may perturb the collection or evaluation procedures are contaminating host DNA [40] or RNA, the existence of viruses such as bacteriophages in the samples, which may impact on the number and genes of microbes [72], and technical issues such as extraction methods (e.g. modified lysostaphin-lysozyme method to enhance staphylococcus DNA extraction) [41].

Currently, most of the publications in human microbiome studies have spotlighted sequencing of $16 \mathrm{~S}$ rRNA in the identification of bacteria. Their results may misjudge the level of diversity and microbial composition by amplification of chimera and pseudogenes and/or inappropriate primer selection. Metagenomic shotgun sequencing may avoid these problems by omitting amplification and allows to detect gene contents of complex microbiota and to compare functional gene contents between samples, but still may have limitations as discussed above and in low-microbial burden samples. However, researchers are now increasingly employing novel techniques to study the human microbiome [25].

\section{Conclusion and perspective of nasal microbiome studies}

The new molecular techniques enhance our chance to identify new bacteria within the nose and nasal cavities; as the pivotal host functions evolved under high microbial pressure, they will show a very complex network of microbes and thus microbe-host interactions [41]. On the host side, specific pheno- and endotypes of CRS have been described characterized by an imbalance of Th1 and Th2 function [71]. In CRSwNP patients, Staphylococcus aureus has been identified to unfold impact on the mucosal immune functions $[10,68,70]$. The relationship between the microbiome and mucosal immunity may be bidirectional, with pressure coming from the bacteria and inadequate defense from the host [70]. Research on how specific bacteria impact on the immune response of nasal and sinus mucosa may shed new light on the pathophysiology of CRS and may result in new strategies for its treatment.

The manipulation of microbiota or the introduction of specifically healthy microbiota may prove to be useful for the treatment of inflammatory disease [73]. Staphylococcus aureus and Pseudomonas aeruginosa are principal offenders in the development of persistent severe airway disease in CRS and CF patients. As bacterial resistance complicates the efficacy of antibiotics, the use of probiotic bacteria as colonizers and antimicrobial agents that may inhibit the growth of pathogenic bacteria awaits further development.

\section{Abbreviations}

CF: Cystic fibrosis; CRS: Chronic rhinosinusitis; CRSwNP: Chronic rhinosinusitis with nasal polyps; DNA: Deoxyribonucleic acid; RNA: Ribonucleic acid; rRNA: Ribosomal ribonucleic acid; bp: Base pairs; FISH: Fluorescence in situ hybridization; PCR: Polymerase chain reaction; QPCR: Quantitative polymerase chain reaction; T-RFLP: Terminal restriction fragment length polymorphism; bTEFAP: Bacterial tag-encoded FLX amplicon pyrosequencing.

\section{Competing interests}

The authors declare that they have no competing interests.

\section{Acknowledgments}

The members of the Committee on Barrier Disease Issues and the Microbiome and the members of the Board of Directors of the World Allergy Organization reviewed and approved this article.

\section{Author details}

'Department of Oto-Rhino-Laryngology, The Upper Airways Research Laboratory (URL), Ghent University Hospital, Ghent 9000, Belgium.

${ }^{2}$ Department of Otolaryngology, Phramongkutklao Hospital and College of Medicine, Royal Thai Army, Bangkok 10400, Thailand. ${ }^{3}$ Basic Biomedical Sciences Department, Health Faculty, Universidad Industrial de Santander, Bucaramanga, Colombia. ${ }^{4}$ Division of ENT Diseases, Clintec, Karolinska Institutet, Stockholm, Sweden.

Received: 4 August 2014 Accepted: 20 November 2014

Published online: 27 January 2015

\section{References}

1. Herbst T, Sichelstiel A, Schar C, Yadava K, Burki K, Cahenzli J, McCoy K, Marsland BJ, Harris NL: Dysregulation of allergic airway inflammation in the absence of microbial colonization. Am J Respir Crit Care Med 2011, 184:198-205.

2. Hormannsperger G, Clavel T, Haller D: Gut matters: microbe-host interactions in allergic diseases. J Allergy Clin Immunol 2012, 129:1452-1459.

3. Strachan DP: Hay fever, hygiene, and household size. BMJ 1989, 299:1259-1260.

4. Ursell LK, Clemente JC, Rideout JR, Gevers D, Caporaso JG, Knight R: The interpersonal and intrapersonal diversity of human-associated microbiota in key body sites. J Allergy Clin Immunol 2012, 129:1204-1208.

5. Human Microbiome Project Consortium: A framework for human microbiome research. Nature 2012, 486(7402):215-221.

6. Goldstein-Daruech N, Cope EK, Zhao KQ, Vukovic K, Kofonow JM, Doghramji L, Gonzalez B, Chiu AG, Kennedy DW, Palmer JN, Leid JG, Kreindler JL, Cohen NA: Tobacco smoke mediated induction of sinonasal microbial biofilms. PLoS One 2011, 6:e15700.

7. Huang YJ: Asthma microbiome studies and the potential for new therapeutic strategies. Curr Allergy Asthma Rep 2013, 13(5):453-461.

8. Huang YJ, Lynch SV: The emerging relationship between the airway microbiota and chronic respiratory disease: clinical implications. Expert Rev Respir Med 2011, 5:809-821.

9. Lynch SV, Bruce KD: The cystic fibrosis airway microbiome. Cold Spring Harb Perspect Med 2013, 3:a009738.

10. Suzaki H, Watanabe S, Pawankar R: Rhinosinusitis and asthma-microbiome and new perspectives. Curr Opin Allergy Clin Immunol 2013, 13:45-49. 
11. Marsland BJ: Regulation of inflammatory responses by the commensal microbiota. Thorax 2012, 67:93-94.

12. Jany $\lrcorner$, Barbier G: Culture-independent methods for identifying microbial communities in cheese. Food Microbiol 2008, 25:839-848.

13. Amann Rl, Ludwig W, Schleifer KH: Phylogenetic identification and in situ detection of individual microbial cells without cultivation. Microbiol Rev 1995, 59:143-169.

14. Vartoukian SR, Palmer RM, Wade WG: Strategies for culture of 'Unculturable' bacteria. FEMS Microbiol Lett 2010, 309:1-7.

15. Su C, Lei L, Duan Y, Zhang KQ, Yang J: Culture-independent methods for studying environmental microorganisms: methods, application, and perspective. Appl Microbiol Biotechnol 2012, 93:993-1003.

16. Orphan VJ, Taylor LT, Hafenbradl D, Delong EF: Culture-dependent and culture-independent characterization of microbial assemblages associated with high-temperature petroleum reservoirs. Appl Environ Microbiol 2000, 66:700-711.

17. Abreu NA, Nagalingam NA, Song Y, Roediger FC, Pletcher SD, Goldberg AN, Lynch SV: Sinus microbiome diversity depletion and corynebacterium tuberculostearicum enrichment mediates rhinosinusitis. Sci Trans/ Med 2012, 4:151ra24.

18. Boase S, Foreman A, Cleland E, Tan L, Melton-Kreft R, Pant H, Hu FZ, Ehrlich GD, Wormald PJ: The microbiome of chronic rhinosinusitis: culture, molecular diagnostics and biofilm detection. BMC Infect Dis 2013, 13:210.

19. Hugenholtz P, Goebel BM, Pace NR: Impact of culture-independent studies on the emerging phylogenetic view of bacterial diversity. J Bacteriol 1998, 180:4765-4774.

20. Nocker A, Burr M, Camper AK: Genotypic microbial community profiling: a critical technical review. Microb Ecol 2007, 54:276-289.

21. Schluenzen F, Tocilj A, Zarivach R, Harms J, Gluehmann M, Janell D, Bashan A, Bartels H, Agmon I, Franceschi F, Yonath A: Structure of functionally activated small ribosomal subunit at 3.3 angstroms resolution. Cell 2000 , 102:615-623.

22. Janda JM, Abbott SL: $16 \mathrm{~s}$ rrna gene sequencing for bacterial identification in the diagnostic laboratory: pluses, perils, and pitfalls. J Clin Microbiol 2007, 45:2761-2764.

23. Claesson MJ, Wang Q, O'Sullivan O, Greene-Diniz R, Cole JR, Ross RP, O'Toole PW: Comparison of two next-generation sequencing technologies for resolving highly complex microbiota composition using tandem variable 16 s rrna gene regions. Nucleic Acids Res 2010, 38:e200.

24. von Wintzingerode F, Gobel UB, Stackebrandt E: Determination of microbial diversity in environmental samples: pitfalls of Pcr-based rrna analysis. FEMS Microbiol Rev 1997, 21:213-229.

25. Kim BS, Jeon YS, Chun J: Current status and future promise of the human microbiome. Pediatr Gastroenterol Hepatol Nutr 2013, 16:71-79.

26. Mardis ER: Next-generation sequencing platforms. Annu Rev Anal Chem (Palo Alto, Calif) 2013, 6:287-303.

27. Charlson ES, Bittinger $K$, Haas AR, Fitzgerald AS, Frank I, Yadav A Bushman FD, Collman RG: Topographical continuity of bacterial populations in the healthy human respiratory tract. Am J Respir Crit Care Med 2011, 184:957-963.

28. Noverr MC, Huffnagle GB: The 'Microflora Hypothesis' of allergic diseases. Clin Exp Allergy 2005, 35:1511-1520.

29. Abrahamsson TR, Jakobsson HE, Andersson AF, Bjorksten B, Engstrand L, Jenmalm MC: Low gut microbiota diversity in early infancy precedes asthma at school age. Clin Exp Allergy 2013, 44(6):842-50.

30. Bisgaard H, Li N, Bonnelykke K, Chawes BL, Skov T, Paludan-Muller G, Stokholm J, Smith B, Krogfelt KA: Reduced diversity of the intestinal microbiota during infancy is associated with increased risk of allergic disease at school age. J Allergy Clin Immunol 2011, 128:646-52 e1-5.

31. Sjogren YM, Jenmalm MC, Bottcher MF, Bjorksten B, Sverremark-Ekstrom E: Altered early infant gut microbiota in children developing allergy up to 5 years of age. Clin Exp Allergy 2009, 39:518-526.

32. Clemente JC, Ursell LK, Parfrey LW, Knight R: The impact of the gut microbiota on human health: an integrative view. Cell 2012, 148:1258-1270.

33. Toh ZQ, Anzela A, Tang ML, Licciardi PV: Probiotic therapy as a novel approach for allergic disease. Front Pharmacol 2012, 3:171.

34. Storro O, Avershina E, Rudi K: Diversity of intestinal microbiota in infancy and the risk of allergic disease in childhood. Curr Opin Allergy Clin Immunol 2013, 13:257-262
35. West CE, Jenmalm MC, Prescott SL: The gut microbiota and its role in the development of allergic disease: a wider perspective. Clin Exp Allergy 2014. [Epub ahead of print]

36. Hansel TT, Johnston SL, Openshaw PJ: Microbes and mucosal immune responses in asthma. Lancet 2013, 381:861-873.

37. Fodor AA, Klem ER, Gilpin DF, Elborn JS, Boucher RC, Tunney MM, Wolfgang MC: The adult cystic fibrosis airway microbiota is stable over time and infection type, and highly resilient to antibiotic treatment of exacerbations. PLoS One 2012, 7:e45001.

38. Zemanick ET, Sagel SD, Harris JK: The airway microbiome in cystic fibrosis and implications for treatment. Curr Opin Pediatr 2011, 23:319-324.

39. Delhaes L, Monchy S, Frealle E, Hubans C, Salleron J, Leroy S, Prevotat A, Wallet F, Wallaert B, Dei-Cas E, Sime-Ngando T, Chabe M, Viscogliosi E: The airway microbiota in cystic fibrosis: a complex fungal and bacterial community-implications for therapeutic management. PLoS One 2012, 7:e36313.

40. Lim YW, Schmieder R, Haynes M, Willner D, Furlan M, Youle M, Abbott K, Edwards R, Evangelista J, Conrad D, Rohwer F: Metagenomics and metatranscriptomics: windows on Cf-associated viral and microbial communities. J Cyst Fibros 2013, 12(2):154-64.

41. Zhao J, Carmody LA, Kalikin LM, Li J, Petrosino JF, Schloss PD, Young VB, LiPuma JJ: Impact of enhanced staphylococcus DNA extraction on microbial community measures in cystic fibrosis sputum. PLoS One 2012, 7:e33127.

42. Zhao J, Schloss PD, Kalikin LM, Carmody LA, Foster BK, Petrosino JF, Cavalcoli JD, VanDevanter DR, Murray S, Li JZ, Young VB, LiPuma JJ: Decade-long bacterial community dynamics in cystic fibrosis airways. Proc Natl Acad Sci U S A 2012, 109:5809-5814.

43. Liu CM, Soldanova K, Nordstrom L, Dwan MG, Moss OL, Contente-Cuomo TL, Keim P, Price LB, Lane AP: Medical therapy reduces microbiota diversity and evenness in surgically recalcitrant chronic rhinosinusitis. Int Forum Allergy Rhinol 2013, 3(10):775-81.

44. Stressmann FA, Rogers GB, van der Gast CJ, Marsh P, Vermeer LS, Carroll MP, Hoffman L, Daniels TW, Patel N, Forbes B, Bruce KD: Long-term cultivationindependent microbial diversity analysis demonstrates that bacterial communities infecting the adult cystic fibrosis lung show stability and resilience. Thorax 2012, 67:867-873.

45. Rogers GB, Carroll MP, Bruce KD: Studying bacterial infections through culture-independent approaches. J Med Microbiol 2009, 58:1401-1418.

46. Zemanick ET, Harris JK, Wagner BD, Robertson CE, Sagel SD, Stevens MJ, Accurso FJ, Laguna TA: Inflammation and airway microbiota during cystic fibrosis pulmonary exacerbations. PLoS One 2013, 8:e62917.

47. Rabin HR, Surette MG: The cystic fibrosis airway microbiome. Curr Opin Pulm Med 2012, 18:622-627.

48. Surette MG: The cystic fibrosis lung microbiome. Ann Am Thorac Soc 2014, 11:s61-s65.

49. Salipante SJ, Sengupta DJ, Rosenthal C, Costa G, Spangler J, Sims EH, Jacobs MA, Miller SI, Hoogestraat DR, Cookson BT, McCoy C, Matsen FA, Shendure J, Lee CC, Harkins TT, Hoffman NG: Rapid 16 s rrna nextgeneration sequencing of polymicrobial clinical samples for diagnosis of complex bacterial infections. PLoS One 2013, 8:e65226.

50. Guss AM, Roeselers G, Newton IL, Young CR, Klepac-Ceraj V, Lory S, Cavanaugh CM: Phylogenetic and metabolic diversity of bacteria associated with cystic fibrosis. ISME J 2011, 5:20-29.

51. Sibley CD, Grinwis ME, Field TR, Eshaghurshan CS, Faria MM, Dowd SE, Parkins MD, Rabin HR, Surette MG: Culture enriched molecular profiling of the cystic fibrosis airway microbiome. PLoS One 2011, 6:e22702.

52. Cox MJ, Allgaier M, Taylor B, Baek MS, Huang YJ, Daly RA, Karaoz U, Andersen GL, Brown R, Fujimura KE, Wu B, Tran D, Koff J, Kleinhenz ME, Nielson D, Brodie EL, Lynch SV: Airway microbiota and pathogen abundance in age-stratified cystic fibrosis patients. PLOS One 2010, 5:e11044.

53. Harris JK, De Groote MA, Sagel SD, Zemanick ET, Kapsner R, Penvari C, Kaess H, Deterding RR, Accurso FJ, Pace NR: Molecular identification of bacteria in bronchoalveolar lavage fluid from children with cystic fibrosis. Proc Natl Acad Sci U S A 2007, 104:20529-20533.

54. Rogers GB, Carroll MP, Serisier DJ, Hockey PM, Jones G, Bruce KD: Characterization of bacterial community diversity in cystic fibrosis lung infections by use of $16 \mathrm{~s}$ ribosomal DNA terminal restriction fragment length polymorphism profiling. J Clin Microbiol 2004, 42:5176-5183.

55. Stressmann FA, Rogers GB, Chan SW, Howarth PH, Harries PG, Bruce KD, Salib RJ: Characterization of bacterial community diversity in chronic 
rhinosinusitis infections using novel culture-independent techniques. Am J Rhinol Allergy 2011, 25:e133-e140.

56. Feazel LM, Robertson CE, Ramakrishnan VR, Frank DN: Microbiome complexity and staphylococcus aureus in chronic rhinosinusitis. Laryngoscope 2012, 122:467-472.

57. Iwase T, Uehara Y, Shinji H, Tajima A, Seo H, Takada K, Agata T, Mizunoe Y: Staphylococcus epidermidis Esp inhibits staphylococcus aureus biofilm formation and nasal colonization. Nature 2010, 465:346-349.

58. Gluck U, Gebbers JO: Ingested probiotics reduce nasal colonization with pathogenic bacteria (staphylococcus aureus, streptococcus pneumoniae, and beta-hemolytic streptococci). Am J Clin Nutr 2003, 77:517-520.

59. Nadel DM, Lanza DC, Kennedy DW: Endoscopically guided cultures in chronic sinusitis. Am J Rhinol 1998, 12:233-241.

60. Stephenson MF, Mfuna L, Dowd SE, Wolcott RD, Barbeau J, Poisson M, James G, Desrosiers M: Molecular characterization of the polymicrobial flora in chronic rhinosinusitis. J Otolanyngol Head Neck Surg 2010, 39:182-187.

61. Ramakrishnan VR, Feazel LM, Gitomer SA, Ir D, Robertson CE, Frank DN: The microbiome of the middle meatus in healthy adults. PLoS One 2013, 8:e85507.

62. Aurora R, Chatterjee D, Hentzleman J, Prasad G, Sindwani R, Sanford T: Contrasting the microbiomes from healthy volunteers and patients with chronic rhinosinusitis. JAMA Otolaryngol Head Neck Surg 2013, 139:1328-1338.

63. Frank DN, Feazel LM, Bessesen MT, Price CS, Janoff EN, Pace NR: The human nasal microbiota and staphylococcus aureus carriage. PLoS One 2010, 5:e10598.

64. Healy DY, Leid JG, Sanderson AR, Hunsaker DH: Biofilms with fungi in chronic rhinosinusitis. Otolaryngol Head Neck Surg 2008, 138:641-647.

65. Sanderson AR, Leid JG, Hunsaker D: Bacterial biofilms on the sinus mucosa of human subjects with chronic rhinosinusitis. Laryngoscope 2006, 116:1121-1126.

66. Lina G, Boutite F, Tristan A, Bes M, Etienne J, Vandenesch F: Bacterial competition for human nasal cavity colonization: role of staphylococcal Agr alleles. Appl Environ Microbiol 2003, 69:18-23.

67. Rasmussen TT, Kirkeby LP, Poulsen K, Reinholdt J, Kilian M: Resident aerobic microbiota of the adult human nasal cavity. APMIS 2000, 108:663-675.

68. Corriveau MN, Zhang N, Holtappels G, Van Roy N, Bachert C: Detection of staphylococcus aureus in nasal tissue with peptide nucleic acidfluorescence in situ hybridization. Am J Rhinol Allergy 2009, 23:461-465.

69. Akdis CA, Bachert C, Cingi C, Dykewicz MS, Hellings PW, Naclerio RM, Schleimer RP, Ledford D: Endotypes and phenotypes of chronic rhinosinusitis: a practall document of the European Academy of Allergy and Clinical Immunology and the American Academy of Allergy, Asthma \& Immunology. J Allergy Clin Immunol 2013, 131:1479-1490.

70. Ba L, Zhang N, Meng J, Zhang J, Lin P, Zhou P, Liu S, Bachert C: The association between bacterial colonization and inflammatory pattern in Chinese chronic rhinosinusitis patients with nasal polyps. Allergy 2011, 66:1296-1303.

71. Van Zele T, Claeys S, Gevaert P, Van Maele G, Holtappels G, Van Cauwenberge $P$, Bachert $C$ : Differentiation of chronic sinus diseases by measurement of inflammatory mediators. Allergy 2006, 61:1280-1289.

72. Rolain JM, Fancello L, Desnues C, Raoult D: Bacteriophages as vehicles of the resistome in cystic fibrosis. J Antimicrob Chemother 2011, 66:2444-2447.

73. Sarowska J, Choroszy-Krol I, Regulska-llow B, Frej-Madrzak M, Jama-Kmiecik A: The therapeutic effect of probiotic bacteria on gastrointestinal diseases. Adv Clin Exp Med 2013, 22:759-766.

\section{Submit your next manuscript to BioMed Central and take full advantage of:}

- Convenient online submission

- Thorough peer review

- No space constraints or color figure charges

- Immediate publication on acceptance

- Inclusion in PubMed, CAS, Scopus and Google Scholar

- Research which is freely available for redistribution

Submit your manuscript at www.biomedcentral.com/submit 